Skidmore College

Creative Matter

\title{
Is Friendship Political in the Land of Opportunity? How Conservative Values Affect Helping Behavior towards Friends
}

Adele Fantasia

Skidmore College, afantasi@skidmore.edu

Follow this and additional works at: https://creativematter.skidmore.edu/socio_stu_stu_schol

Part of the Race and Ethnicity Commons, Social Psychology and Interaction Commons, and the Sociology of Culture Commons

\section{Recommended Citation}

Fantasia, Adele, "Is Friendship Political in the Land of Opportunity? How Conservative Values Affect Helping Behavior towards Friends" (2019). Sociology Senior Seminar Papers. 18.

https://creativematter.skidmore.edu/socio_stu_stu_schol/18

This Thesis is brought to you for free and open access by the Sociology at Creative Matter. It has been accepted for inclusion in Sociology Senior Seminar Papers by an authorized administrator of Creative Matter. For more information, please contact dseiler@skidmore.edu. 
Is Friendship Political in the Land of Opportunity?

How Conservative Values Affect Helping Behavior towards Friends*

Adèle Fantasia

Skidmore College

Word Count $=6,890$

*Please direct all correspondence to Adèle Fantasia, 815 N. Broadway, Skidmore College, Saratoga Springs, NY 12866 or afantasi@skidmore.edu. This research project was conducted with the help of Professor Catherine Berheide and Professor Andrew Lindner, along with colleagues in the Sociology Senior Seminar class. 


\section{Is Friendship Political in the Land of Opportunity? How Conservative Values Affect Helping Behavior Towards Friends}

\section{ABSTRACT}

Individualism operates as a dominant ideology in American society, so how does individualism pervade both people's larger views on society as well as their dyadic relationships? Do world views about the value of hard work and if people deserve help permeate the private sphere in tangible ways? I propose a relationship between individualistic tendencies and the frequency with which individuals help their friends and family who are feeling depressed. I hypothesize that the more the respondent believes that those in need have to learn to take care of themselves, the less frequently they will help a relative, friend, or neighbor who is a bit down or depressed by talking to them. I also hypothesize that the more the respondent believes that people get ahead by their own hard work, the less frequently they will engage in this helping behavior. Finally, I hypothesize that the more conservative the respondent is, the less frequently they will engage in this helping behavior. I test the relationship between these typically conservative values and helping behavior using a sample of 828 respondents from the 2014 General Social Survey (GSS) dataset, controlling for gender, race, age, and education. Results from bivariate and OLS regression analyses report that there is no statistically significant relationship between conservative values and helping behavior, so the hypotheses are not supported. Instead, two control variables impact the dependent variable. Gender has the strongest effect on the frequency with which one helps a relative, friend, or neighbor who is feeling depressed, followed by race. On average, women and people of color engage in more helping behavior. 
Over recent decades, interest in both attitudes towards welfare and motivations for altruism have permeated the field of sociology. By asking how social forces affect altruistic helping behavior, sociologists explore the role of structure within the individual. Structures influence individuals through ideologies, which have the ability to dictate political opinions while also affecting day to day experiences. This research is grounded within that intersection. Past research has failed to focus on how American ideologies that lend themselves to political views, like attitudes towards welfare, impede on individual friendships.

Specific values make up the dominant ideologies in American society. The pillars of the “American dream” are personal freedom and democracy, which contain egalitarianism, individualism, and the importance of hard work. This study focuses on individualism and hard work. These are core elements of American "exceptionalism”, which was first observed by Alexis de Tocqueville during his visit to the U.S. in the 1830s. He observed that democracy eventually produces egoism such that Americans "look after their own needs. They owe nothing to any man, they expect nothing from any man; they acquire the habit of always considering themselves as standing alone, and they are apt to imagine that their whole destiny is in their own hands (De Tocqueville 1969:575). Though conceptions of American “exceptionalism” have shifted over the years, sociologists generally find that many U.S. citizens perceive their society to be a meritocracy, where hard work is the most important way of achieving success. This dominant ideology is known as the achievement ideology. It tends to be part of conservative ideology as it asserts that the path out of misfortune comes from the individual, through hard work and determination (Valadez 2000). 
CONSERVATIVE VALUES AND HELPING BEHAVIOR

Individualism and hard work make up a capitalist society whose welfare system is inferior to that of many Western societies. Welfare is a polarizing issue that is inherently political. This study explores a relationship between the individualistic tendencies of conservativism and solidarity among family and friends. This research aims to study how individuals are affected by a society that values self-sufficiency on a grander level. It is relevant research because in a society, and particularly a political party, that prides itself in traditional family values, it is important to study whether conservatives exercise the same individualism in their intimate relationships as in their political views. This study may add to our knowledge of conservative views, particularly opinions towards the welfare state, and could have policy implications.

The question at the core of this research is whether the individualism that dictates conservative aversion to welfare is in effect when individuals interact with those closest to them. Does large-scale individualism affect small-scale individualism? Do abstract world views about work ethic and if people deserve help permeate the privacy of one's home? Is the hypothetical compassion that is lacking in right wing politics afforded to those the individual knows and loves, thus extending tangible helping behavior towards those people? I hypothesize that the more the respondent believes that those in need have to learn to take care of themselves, the less frequently they will help a relative, friend, or neighbor who is a bit down or depressed by talking to them. Similarly, I hypothesize that the more the respondent believes that people get ahead by their own work, the less frequently they will help a relative, friend, or neighbor who is a bit down or depressed by talking to them. Because those who believe in individualism and hard work may be more conservative, the final hypothesis is that the more conservative the 
CONSERVATIVE VALUES AND HELPING BEHAVIOR

respondent is, the less frequently they will help a relative, friend, or neighbor who is a bit down or depressed by talking to them.

\section{THEORY}

Organic Solidarity

Emile Durkheim's “organic solidarity” functions as the theoretical framework for this study. Durkheim describes organic solidarity in his 1893 book The Division of Labor in Society in the context of his seminal anomie theory. He discusses the impact of modernization, and describes an organic solidarity that resulted from capitalism. With the division of labor, individuals played more specialized roles in society, and though they depended on each other more, there was more variation in their individual experiences. Social bonds weakened as collective values and beliefs became less common. This lack of "collective conscience" led to increased egoistic behavior that fostered disorder and normlessness, known by Durkheim as “anomie". In his 1897 book Suicide: A Study in Sociology, Durkheim positions "egoistic" suicide, motivated by social isolation, as the ultimate form of societal deviance. His study finds that among Catholics and Protestants, Protestants were more likely to commit egoistic suicide. Protestant culture emphasized individualism, so Durkheim concluded that heightened individualism lead to more suicides motivated by social isolation. Durkheim shows that the individualism of Protestantism led to less social cohesion and more disorderly egoism, therefore I hypothesize that the individualism of conservative values leads to less social cohesion and less helping behavior among individuals.

\section{LITERATURE REVIEW}


CONSERVATIVE VALUES AND HELPING BEHAVIOR

This study explores how the American ideologies that dictate welfare judgements affect altruistic behavior towards family and friends. It tests whether people's beliefs in hard work and individualism carries over to their immediate relationships. Therefore, both American individualism and altruistic helping behavior are implicated in this study. Much research has been done on perceptions of an American meritocracy and much research has been done on motivations for altruism, but few studies have mapped the effect of the former on the latter. A review of past research follows in the form of four general themes: achievement ideology, attribution theory, attitudes towards welfare, and altruism.

\section{Achievement Ideology}

Research on perceptions of an American meritocracy has focused mainly on people's attitudes about what it takes to succeed, and what factors influence these attitudes (Barnes 2002; Reynolds and Xian 2014). Studies of this sort demonstrate the power of the achievement ideology, confirming its role as a dominant ideology in the U.S. Findings show that over time, Americans in general maintain the belief that hard work, ambition, and education are most important for getting ahead (Reynolds and Xian 2014). Research reports similar findings when studying particular social groups, showing that social factors do not influence perceptions of a meritocracy; “...results indicate that regardless of race/ethnicity, sex, household economics, or neighborhood poverty, respondents embrace an achievement ideology that acknowledges the importance of education and hard work" (Barnes 2002:222). Residents in poor urban neighborhoods do not reflect an oppositional culture, instead, they accept the cultural narrative that success is intrinsically motivated. The findings suggest that the people who are affected by a lack of substantial government assistance in the U.S. may conceive of their economic failure as individually caused. 


\section{CONSERVATIVE VALUES AND HELPING BEHAVIOR}

\section{Attribution}

The relationship between individualistic ideologies and helping behavior in friendship is informed by attribution theory, which states that individuals assign causes to behaviors and actions to make meaning of events. Research that focuses on beliefs about the causes of poverty study a different side of the achievement ideology, that being the role the individual plays in their "failure", rather than their "success", like in the aforementioned studies. These studies also confirm the strong presence of an achievement ideology in the U.S. Results show that Americans attribute individual responsibility to be the most prominent reason for poverty, therefore the findings suggest that respondents may blame poor people themselves for their poverty (Cozzarelli, Wilkinson, and Tagler 2001; Fischer 2008; Smith and Stone 1998). Research on attitudes towards poverty shows that the causes of poverty are attributed to three categories: individualistic explanations, structural explanations, and fatalistic explanations (Feagin 1972). Further research builds off of attributional tendencies to study how causal explanations of poverty manifest in behavior, specifically helping behavior (Zucker and Weiner 1993). The findings suggest that though welfare judgements are directly related to attributions of responsibility and political ideology, personal help is emotionally determined. The study at hand tests whether Zucker and Weiner's findings remain true today.

\section{Welfare}

Americans' perceptions of success and failure correspond to their attitudes toward social welfare. Beliefs about individualism and whether hard work creates a path to success, which contribute to conservative values, are closely associated with anti-welfare sentiment. Previous literature has studied how social variables dictate support for government aid (Hasenfeld and Rafferty 1989; Jeene et al. 2013; Mattis et al. 2008). Studies find that both social factors and 


\section{CONSERVATIVE VALUES AND HELPING BEHAVIOR}

ideologies contribute to attitudes toward welfare; "support of welfare state programs is a function of self-interest and the resultant identification with dominant social ideologies- work ethic and social equality. Identification with these ideologies, in turn, affects endorsement of social rights and, hence, support of welfare state programs... The findings suggest that the social groups supporting the welfare state are the economically and socially vulnerable who identify with social democratic values" (Hasenfeld and Rafferty 1989:1044). Among the economically and socially vulnerable, both self-interest and predetermined social democratic values contribute to support for welfare. Another study contests the importance of self-interest; "the altruistic concern for the well-being of the less well-off leads many affluent Americans to support antipoverty policies and the Democratic Party... Altruism matters little for low-income Americans' preferences and partisanship, but has substantively large effects on the affluent" (Gilens and Thal 2018:210). This finding may suggest that self-interest, influenced by social factors, is less important than ideology.

By default, exclusively American samples control for pervasive dominant ideologies, since all American respondents are affected by them to a certain extent. Studying other societies allows for a comparison of the effect of social democracies and their respective ideologies on individual perceptions. Much research on welfare combines aggregate-level and individual-level data to study how the strength of a welfare system corresponds to individual perceptions of welfare. Studies of this type support the flexibility of ideologies across cultures. Because ideologies shift across societies, together social ideologies and social forces are at work in the social reproduction of attitudes towards welfare. Aggregate-level research generally finds that citizens of societies with stronger welfare systems are more in favor of welfare, which confirms 


\section{CONSERVATIVE VALUES AND HELPING BEHAVIOR}

the idea that social environments of ideologies dictate individual attitudes (Delhey and Dragolov 2014; Hans-Jurgen and Heien 2001; Kunovich et al. 2007).

\section{Altruism}

Lots of literature exists on the topic of altruism. "Although scholars' definitions differ, most would agree that altruism (1) seeks to increase another's welfare, not one's own; (2) is voluntary; (3) is intentional, meant to help someone else; and (4) expects no external reward" (Simmons 1991:3). Altruistic behavior takes many forms, but it tends to refer to financial charity and kindness towards strangers. This study is grounded in the non-monetized selflessness found in more intimate relationships among friends, relatives, and neighbors. Generally, research on altruism tackles whether true altruism really exists by studying what motivates people to engage in altruistic helping behavior. Much of the literature also focuses on the effect of social factors on altruistic behavior, unlike this research which studies ideology impacts altruistic behavior.

A review of the literature on altruism finds that women on average engage in helping behavior more than men. Research shows that women volunteer more (Fletcher and Major 2004), they contribute more to poverty relief organizations (Willer, Wimer, and Owens 2015), and they behave more altruistically towards their children (Quiyan and Ho 2013). Further, research finds that women are more solidary (Arts and Gelissen 2001) and more compassionate than men; "females in our sample are more likely than males to express concern and responsibility for the well-being of others, less likely than males to accept materialism and competition, and more likely than males to indicate that finding purpose and meaning in life is extremely important" (Beutel and Marini 1995:440). These findings suggest that altruism is a gendered phenomenon because women are socialized to be less individualistic, so they engage more in altruistic behavior. Research shows that charitable acts and volunteering are common 


\section{CONSERVATIVE VALUES AND HELPING BEHAVIOR}

when they are embedded in the social structure of a community (Eckstein 2001). This speaks to the importance of dominant culture and ideologies in establishing norms for altruism.

The term altruism describes the concept at the core of helping behavior, a concept that gets at the motivation for helping, which can be selfless. The study at hand departs from the literature's more conceptual look at altruism and directs it at concrete expressions of helping, as opposed to the feelings and motivations that contribute to helping. Furthermore, helping behavior finds itself in between the concepts of altruism and friendship, so the literature on altruism is not acute enough to describe patterns in the particular topic of interest.

Past literature on the achievement ideology shows how strongly Americans believe in hard work, regardless of social identity. The literature on attribution theory shows how the achievement ideology and attribution come together in that Americans attribute individual responsibility to be the most prominent reason for poverty. In regard to attitudes towards welfare, the literature is divided on whether it is more determined by self-interest (similar social identities) or ideology. Aggregate-level and individual-level research finds that citizens of societies with stronger welfare systems are more in favor of welfare, which suggests the power of ideology. Research on altruism shows a gendered pattern. Women volunteer their time and money more, they are more altruistic parents, and they are more solidary and compassionate.

\section{METHODS}

The findings are drawn from a secondary analysis of the 2014 General Social Survey (GSS) (Smith et al. 2014). The GSS administers surveys to English and Spanish speaking Americans above the age of eighteen who are not institutionalized. Since 1972, every two years 


\section{CONSERVATIVE VALUES AND HELPING BEHAVIOR}

the GSS administers 90-minute in-home surveys with a random sample of less than 5,000 Americans. The unit of analysis is the individual.

In 2014, the GSS response rate was 60.2 percent. A subset of respondents answered questions from the Social Networks and Support Systems Module of the General Social Survey. Because my interest lies in exploring the connection between individualistic beliefs and helping behavior towards friends, I restrict the analysis to 828 individuals who were administered the Social Networks and Support Systems module from which I pull the dependent variable, the Core questions that I use as the independent variables, and for whom there is complete information on the control variables. These three elements align in 2014 and thus restrict the study to that year. Missing data also limits the sample size. Cases with missing data have been deleted through the listwise missing data process. Inapplicable responses, "don't know" responses, and "no answer" responses have been removed from the sample. More information on how the General Social Survey data was collected can be found by visiting the General Social Survey website at (http://gss.norc.org/) under the frequently asked questions section (Smith et al. 2014).

To assess the frequency with which the respondent has helped someone they know personally by talking to them when they felt depressed, individuals were asked at the beginning of the module: "During the past 12 months, how often have you done any of the following things for people you know personally, such as relatives, friends, neighbors or other acquaintances?" I have chosen to focus on the specific "talked to" variable, which states: "spent time talking with someone who was a bit down or depressed", and requires respondents to answer by indicating how often they have done so in the past year. I recoded the variable into an interval ratio variable, which measures frequency numerically. The answer values are: 104= more than once a 
CONSERVATIVE VALUES AND HELPING BEHAVIOR

week, $52=$ once a week, $12=$ once a month. $2.5=$ at least two or three times in the past year, $1=$ once in the past year, $0=$ not at all in the past year.

For this study, I conceptualize the "talked to" variable as demonstrating the level of helping behavior one exercises among the people they are closest to. Having disregarded variables that measure helping relatives, friends, and neighbors with housework or shopping, helping them find a job, and lending them money, I find that the "talked to" variable gets at the core of the altruistic element of the dependent variable by ignoring monetary means of helping. Removing the explicitly transactional elements of the dependent variable allows effort in friendship to be measured through time spent helping friends during a hard time. The "talked to" variable is referred to as "helping behavior" throughout this study.

The key interest of this study lies in the relationship between individualism and helping behavior. We operationalize how individualistic a respondent is by asking them a question about individual responsibility; the survey states: "those in need have to learn to take care of themselves and not depend on others" and the respondent must respond on a likert-scale with how much they agree. I have recoded the answer values so that the higher the number, the more the respondent agrees with the statement, meaning the more the respondent believes in individual responsibility. The answer values are like so: $1=$ strongly disagree, $2=$ disagree, $3=$ neither agree nor disagree, $4=$ agree, $5=$ strongly agree. This variable is referred to as "individual responsibility" or "belief in individualism" throughout this study.

The other key interest of this study lies in the relationship between individuals' perceptions of a meritocracy and helping behavior. Perceptions of a meritocracy is the theme that is operationalized through opinions of how people "get ahead". The variable "get ahead" asks individuals: "Some people say that people get ahead by their own hard work; others say that 


\section{CONSERVATIVE VALUES AND HELPING BEHAVIOR}

lucky breaks or help from other people are more important. Which do you think is most important?" I have recoded the answer values so that the higher the answer value, the more one believes in hard work. The answer values are: $1=$ luck or help from others most important, $2=$ both equally important, $3=$ hard work most important.

The final independent variable is political views. The question is posed this way: "We hear a lot of talk these days about liberals and conservatives. I'm going to show you a sevenpoint scale on which the political views that people might hold are arranged from extremely liberal--point 1--to extremely conservative--point 7 . Where would you place yourself on this scale?" The answer values are: $1=$ extremely liberal, $2=$ liberal $3=$ slightly liberal $4=$ moderate, middle of the road $5=$ slightly conservative $6=$ conservative $7=$ extremely conservative."

The first control variable is gender, which is operationalized through the GSS' binary variable called "sex". "Respondent's sex" has been recoded into a dummy variable so that men are the reference group, 0 , and women are 1 . The second control variable is race. The answer values have been recoded into a dummy variable so that the reference group is non-white (black and other) and 1 is white. Another control variable is "age". The variable has not been manipulated, it is an interval ratio variable, but all ages after 89 are put in the 89 year old category. The next is "education", which is an interval measure of the highest year of school the respondent completed. The answer values range from 0 to 20 .

\section{FINDINGS}

\section{Univariate Findings}

Table 1 shows the frequency with which respondents talk to a friend, relative, or neighbor who is a bit down or depressed over the course of the year. The median value among respondents 
CONSERVATIVE VALUES AND HELPING BEHAVIOR

is 12 . Figure 1 shows that 32 percent of respondents chose 12, so the modal response was talking to a friend who was depressed once a month.

TABLE 1 ABOUT HERE

FIGURE 1 ABOUT HERE

Table 1 shows that most of the respondents either agree that people need to learn to take care of themselves and not depend on others or neither agree nor disagree with the statement. Figure 2 shows that most of the respondents, 40 percent, agree with the statement, and table 1 reiterates this in the median value. It is also important to note that the number of respondents who strongly agree with the statement more than triples the number of respondents who strongly disagree with the statement.

\section{FIGURE 2 ABOUT HERE}

Table 1 shows that the median for the "get ahead" question is 3 , and figure 3 shows that 69 percent of respondents believe hard work is the most important in getting ahead. The second most robust answer is "both equally", with 20 percent of respondents choosing this answer. 11 percent believe in luck and help.

\section{FIGURE 3 ABOUT HERE}

Table 1 and figure 4 show that most respondents, 40 percent, describe themselves as moderate. Only 8 percent of respondents describe themselves as more politically radical, with 4 percent labeling themselves as extremely liberal, and 4 percent labeling themselves as extremely conservative. There is a relatively even distribution of the other categories.

\section{FIGURE 4 ABOUT HERE}

Among the control variables, the number of men and women in this sample are practically equal. Figure 5 shows that 52 percent of respondents are female. Table 1 shows us the 


\section{CONSERVATIVE VALUES AND HELPING BEHAVIOR}

distribution among white respondents and people of color, with 76 percent being white. Figure 6 gives us a visual of this break down. According to table 1, the average age of respondents is 44 years of age. In a histogram, figure 7 shows us the distribution of ages in the sample and demonstrates an unsteady decline in people above the age of 60 . Table 1 shows us that the majority of respondents have just a high school degree, and the second largest response is "some college". Figure 8 shows us that 27 percent of respondents have just a high school degree, 25 percent have done some college, and the percent that have less than a high school degree is less than the number of people who have a college degree.

\section{FIGURE 5, 6, 7 ABOUT HERE}

\section{Bivariate Findings}

Correlation coefficients are used to determine bivariate relationships between the independent, dependent, and control variables. Table 2 reports statistically significant relationships between several control variables and the dependent variable, as well as statistically significant relationships between several independent variables and control variables. However, there are no relationships between the independent variables and the dependent variable. The following relationships are statistically significant at the $.01 \mathrm{p}$ level. The table shows a weak and positive relationship between gender and talking to a depressed friend. This means that on average women talk to depressed friends more frequently. Race has a very weak and negative relationship with talking to a depressed friend. This means that on average people of color talk to depressed friends more frequently.

The following relationships are between independent variables and controls, not the dependent variable. There is a very weak and positive relationship between individual responsibility and both conservativism and age. This means that the older and more conservative 
CONSERVATIVE VALUES AND HELPING BEHAVIOR

the respondent is, the more likely they will believe in individual responsibility. There is a very weak and negative relationship between individual responsibility and gender. This means that male respondents on average believe more strongly in individual responsibility. There is also a very weak and positive relationship between conservativism and race, meaning that white people are more likely to be conservative.

\section{Multivariate Findings}

In table 3, OLS regression results show that 7.6 percent of the variability in the talked to depressed friend variable can be explained by individual responsibility, get ahead, political views, gender, race, age, and education. The regression equation is statistically significant at the .01 level. The regression coefficients for two of the control variables, gender and race, are statistically significant at the .01 level. The independent variables and the rest of the control variables are not statistically significant at that alpha level. Controlling for all other variables, the regression results show that on average, women talk to family or friends who are feeling depressed almost seventeen more times a year than men. All else being equal, people of color on average talk to family or friends who are feeling depressed almost nine more times a year than white people. Net of all other factors, though both have statistically significant effects on the dependent variable, gender $(\beta=.220)$ has a more powerful effect than race $(\beta=-.098)$.

\section{DISCUSSION}

The findings show that the hypothesis is not supported; belief in individual responsibility, belief in hard work, and conservativism do not have an effect on the frequency with which respondents help family or friends who are down or depressed. Those who believe in individualism and that generally people are on their own and should not depend on others do not 


\section{CONSERVATIVE VALUES AND HELPING BEHAVIOR}

act accordingly with their friends or family who are feeling sad. They do not behave as though they believe the people they interact with on a daily basis should "learn to take care of themselves" when times are tough, instead they help them by talking to them just as much as those who do not have those beliefs.

The results indicate that Durkheim's theory of "organic solidarity" is not supported by this hypothesis. During modernization, Durkheim theorized that the division of labor would foster individuality while limiting the "collective conscience", leading to a general decrease in social cohesion. He proved this by finding that the individualism of Protestantism led to less social cohesion and more disorderly egoism in the form of suicide, therefore I ask whether the individualism of conservative values leads to less social cohesion and less helping behavior among individuals in contemporary American society. Though American society is increasingly influenced by capitalist tendencies, Durkheim's “organic solidarity” does not provide a substantial theory for how individualism affects individuals in modern society. This study's findings suggest that individualistic beliefs may never have had a direct effect on helping behavior, or that the effect is not present in American society currently.

There is no relationship between conservative values and helping behavior, but this research suggests effects of both race and gender. Multivariate regression results show that people of color on average help depressed family or friends by talking to them nine more times a year than white people. Gender has the strongest relationship with helping behavior, as OLS regression finds that women on average help depressed family or friends by talking to them seventeen more times a year than men. White men talk to sad family members or friends the least. 
CONSERVATIVE VALUES AND HELPING BEHAVIOR

Women are socialized to be more emotional and nurturing than men, and this relationship between women and helping behavior confirms the literature on the gendered nature of altruism. Various studies report that women are generally more likely than men to engage in altruistic helping behavior. They volunteer more (Fletcher and Major 2004), they contribute more to poverty relief organizations (Willer, Wimer, and Owens 2015), they are more altruistic parents (Quiyan and Ho 2013), and they are more solidary (Arts and Gelissen 2001) and compassionate than men (Beutel and Marini 1995). Women are overall less individualistic than men, and generally they engage in more altruistic helping behavior.

Gender, mediated by individualism, has the power to impact people's helping behavior, but ideological measures of individualism do not have this power. Ideologies, such as the achievement ideology, are powerful in attributing attitudes towards world views or political issues like welfare (Cozzarelli, Wilkinson, and Tagler 2001; Fischer 2008; Smith and Stone 1998), but this study shows they may not have an impact on how people interact with those they are close to. This supports previous literature that finds that attributions of responsibility and political ideology have an effect on welfare judgements, but they do not have an effect on personal help, which is emotionally determined (Zucker and Weiner 1993). American ideologies are embedded in our value system, and determine how we see the world, but gender is embedded in our personal identity and these findings suggest that it affects the way we operate in dyadic interactions.

This study confirms that personal help is emotionally motivated, meaning the ideological attribution of responsibility does not permeate the personal sphere. The respondents belief in individualism does not inhibit their helping behavior. This suggests a gap in ideological thinking and practical behavior. Attributions of responsibility may become less important as people spend 


\section{CONSERVATIVE VALUES AND HELPING BEHAVIOR}

more time with those subject to misfortune. This suggests that exposure may be significant because mere exposure theory shows how people have less negative prejudice towards the things they are familiar with. Exposure may allow people to view those who are struggling not as groups represented in the media, but as people who may be depressed due to money problems, for instance. With higher exposure, instead of reacting to people with individualistic ideological responses, they may have more compassion because they understand and care. Exposure to people who are struggling may not be enough; it is likely that one must be close with the family member or friend to be able to reconcile ideology and daily life, but exposure to people with different experiences is a productive place to begin deconstructing attributions of responsibility and start humanizing people who are having a tough time.

\section{CONCLUSION}

This study explores the role dominant ideology plays in small scale interactions. It explores whether world views about the value of hard work and if people deserve help, typically conservative values, impact how altruistic people are in their close relationships. I hypothesized that the more the respondent believes that those in need have to learn to take care of themselves, the less frequently they will help a relative, friend, or neighbor who is a bit down or depressed by talking to them. Further, I hypothesized that the more the respondent believes that people get ahead by their own hard work, the less frequently they will engage in this helping behavior. Finally, I hypothesized that the more conservative the respondent is, the less frequently they will engage in this helping behavior. I tested the relationship between these typically conservative values and helping behavior using a sample of 828 respondents from the 2014 GSS dataset, controlling for gender, race, age, and education. The findings suggest that there is no relationship 


\section{CONSERVATIVE VALUES AND HELPING BEHAVIOR}

between individualistic values and helping behavior. Ideological beliefs about individualism do not have an effect on how much an individual helps a depressed family member or friend by talking to them. This ideology does not permeate this facet of the private sphere, but gender and race do. Gender has the strongest effect on helping behavior, followed by race.

Durkheim's “organic solidarity” does not provide a theoretical framework that grounds this study accurately. The lack of a relationship between the variables suggests the insignificance of ideological individualism. Ideologies of individualism do not play a tangible role in people's friendships, but social identity does. Future research would benefit from an increased interest in the elements that construct ideologies. How do identities, instead of ideologies, influence the way people navigate the social world? How do ideologies infiltrate identities? Understanding this will researchers to better grapple with the gap between ideological thinking and practical behavior. Reconciling the difference between attitudes towards the social world and engagement in it could encourage people to extend the same compassion in their political views as in their close relationships. Maybe its possible to transmit understanding from the small-scale to the large-scale. It could be done through exposure, ultimately affecting people's attitudes towards welfare, which could affect voting patterns. But further research will be necessary in beginning to dismantle the attribution of responsibility in an attempt to make American society a more collective and less individualistic one.

\section{Limitations}

As with all research, this study was not without limitations. There are many ways to measure the dependent variable, altruism in friendship. The way this variable operationalizes helping behavior in friendship is susceptible to invalid or unreliable responses. As with most research designs, the questions asked must be interpreted by the subject. The question asks how 


\section{CONSERVATIVE VALUES AND HELPING BEHAVIOR}

much the respondent talks to a family member or a friend who was a bit down or depressed. The use of the word "depressed" could affect responses. I attempt to operationalize the concept of talking to a friend who needs help in general, and the element of depression does not need to be included. Respondents may have responded with an invalid response if they took the term depressed literally and found that they do not have any depressed friends. Similarly, stigma may influence this conclusion if the respondent does not acknowledge the validity of mental health issues. Another issue with this question is that it asks the respondent to remember specific actions, as opposed to questions that ask about personal opinions. The respondent may not accurately remember how many times in the past year they engaged in this helping behavior. Further, as there are countless ways to be a good friend, therefore countless ways to operationalize social cohesion, some respondents may not identify with this form of helping behavior. This may be because job responsibilities or parenting responsibilities simply do not allow them any time to care for friends in this way. There are other ways to be a good friend, and there probably would have been different responses if the question had asked about monetary helping behavior. Future research will operationalize altruism in friendship without using the word depression, and will include a comprehensive index of helping behavior measures so as not to rely on one example of helping behavior.

\section{Future Research}

The pervasive individualism Durkheim describes during modernization only increases in contemporary life. As capitalism further orients itself toward efficiency and productivity, society increasingly prioritizes the individual. This study asks whether ideological individualism, a typically conservative tendency, has a direct effect on societal atomization. The findings show that those who believe in an ideology of individualism are not less solidary in their friendships 
CONSERVATIVE VALUES AND HELPING BEHAVIOR

than those who do not. The limited power this dominant ideology appears to hold offers a hopeful outlook, and it allows researchers to take the study of friendship in a different direction. Further research should explore more practical factors that could contribute to a decrease in social bonds, like social media usage. Future research should also explore the way certain social identities foster more group solidarity. White men were found to engage in this helping behavior the least. An exploration of the weaker social bonds among this demographic would be useful to the field. What about being a woman and being a person of color makes people talk to their friends more? The research shows that women are socialized to be more nurturing and empathetic. Literature on race was not included in this study, but it is the shared experience of being in a marginalized group that would most likely foster solidarity. Women are socialized to care about emotions more than men, but they may also help their friends more because of the experience of being in an oppressed group.

Aggregate-level research on helping behavior would be beneficial to the field, specifically research that tests differences in friendship across countries. This research would show whether citizens of societies with stronger welfare systems are more solidary in their friendships. Researchers could explore whether citizens of the U.S. are more individualistic in their friendships compared to citizens of other societies, instead of whether distinctly American ideologies have differing influences on Americans. However, any further studies will benefit the field and will shed light on the way individualism operates in this country so that it can shift to being a more collective one. 


\section{REFERENCES}

Arts, Will, and John J. Gelissen. 2001. "Welfare States, Solidarity and Justice Principles: Does the Type Really Matter?" Acta Sociologica 44(4):283-299.

Barnes, Sandra L. 2002. "Achievement or Ascription Ideology? An Analysis of Attitudes about Future Success for Residents in Poor Urban Neighborhoods.” Sociological Focus $35(2): 207-225$

Beutel, Ann M., and Margaret M. Marini, M. 1995. “Gender and Values.” American Sociological Review 60(3):436-448.

Cozzarelli, Catherine, Anna V. Wilkinson, and Michael J. Tagler. 2001. "Attitudes Toward the Poor and Attributions for Poverty." Journal of Social Issues 57(2):207-227.

De Tocqueville, Alexis. 1969. Democracy in America. New York: Harper \& Row.

Delhey, Jan, and Georgi Dragolov. 2014. "Why Inequality Makes Europeans Less Happy: The Role of Distrust, Status Anxiety, and Perceived Conflict.” European Sociological Review 30(2):151-165.

Durkheim, Émile. 1893. “On Mechanical and Organic Solidarity.” Pp. 39-43 in Social Theory: Roots and Branches, edited by Peter Kivisto. New York: Oxford University Press.

Durkheim, Émile. 1897. “Anomic Suicide.” Pp. 51-56 in Social Theory: Roots and Branches, edited by Peter Kivisto. New York: Oxford University Press.

Feagin, Joe R. 1972. "Poverty: We Still Believe That God Helps Them Who Help Themselves." Psychology Today 6(1):101-129. 
CONSERVATIVE VALUES AND HELPING BEHAVIOR

Fischer, Claude S. 2008. "Paradoxes of American Individualism.” Sociological Forum 23(2):363-371.

Fletcher, Thomas D., and Debra A. Major. 2004. "Medical Students' Motivations to Volunteer: An Examination of the Nature of Gender Differences." Sex Roles (51)1:109-114

Gilens, Martin, and Adam Thal. 2018. "Doing Well and Doing Good?: How Concern for Others Shapes Policy Preferences and Partisanship among Affluent Americans." Public Opinion Quarterly 82(2):209-230.

Hans-Jurgen, Andre, and Thorsten Heien. 2001. "Four Worlds of Welfare State Attitudes? A Comparison of Germany, Norway, and the United States." European Sociological Review 17(4):337-356.

Hasenfeld, Yeheskel, and Jane A. Rafferty. 1989. "The Determinants of Public Attitudes Toward the Welfare State.” Social Forces 67(4):1027-1048.

Healy, Kieran. 2004. "Altruism as an Organizational Problem: The Case of Organ Procurement." American Sociological Review 69:387-404.

Inglehart, R., Baker, W.E. 2000. "Modernization, Cultural Change, and the Persistence of Traditional Values.” American Sociological Review 65(1):19-51.

Jeene, Marjolein, Wim van Oorschot, and Wilfred Uunk. 2011. "Popular Criteria for the Welfare Deservingness of Disability Pensioners: The Influence of Structural and Cultural Factors." Social Indicators Research 110:1103-1117.

Kunovich, Sheri, and Kazimierz M. Slomczynski. 2007. "Systems of Distribution and a Sense of Equity: A Multilevel Analysis of Meritocratic Attitudes in Post-Industrial Societies." European Sociological Review 23(5):649-663. 


\section{CONSERVATIVE VALUES AND HELPING BEHAVIOR}

Mattis, Jacqueline S., Nyasha A. Grayman, Sheri-Ann Cowie, Cynthia Winston, Carolyn Watson, and Daisy Jackson. 2008. "Intersectional Identities and the Politics of Altruistic Care in a Low-Income, Urban Community.” Sex Roles 59(5-6):418-428.

Reynolds, Jeremy, and He Xian. 2014. "Perceptions of meritocracy in the land of opportunity." Research in Social Stratification \& Mobility 36:121-137.

Shepelak, Norma J., and Duane F. Alwin. 1986. "Beliefs about Inequality and Perceptions of Distributive Justice.” American Sociological Review 51(1):30-46.

Simmons, Roberta G. 1991. “Altruism and Sociology.” The Sociological Quarterly 32(1):1-22/

Smith, Kevin B., Lorene H. Stone. 1989. "Rags, Riches, and Bootstraps: Beliefs about the Causes of Wealth and Poverty." The Sociological Quarterly 30(1):93-107.

Smith, Tom W., Peter Marsden, Michael Hout, and Jibum Kim. General Social Surveys, 2014 [machine-readable data file] /Principal Investigator, Tom W. Smith; Co-Principal Investigator, Peter V. Marsden; Co-Principal Investigator, Michael Hout; Sponsored by National Science Foundation. -NORC ed.- Chicago: NORC at the University of Chicago [producer and distributor]. Data accessed from the GSS Data Explorer website at gssdataexplorer.norc.org.

Valadez, J. R. 2000. "Searching for a Path out of Poverty: Exploring the Achievement Ideology of a Rural Community College.” Adult Education Quarterly 50(3):212-230.

Willer, Robb, Christopher Wimer, and Lindsay A. Owens. 2015. "What drives the gender gap in charitable giving? Lower empathy leads men to give less to poverty relief." Social Science Research 52:83-98 
Qiyan, Ong, and Kong Ho. 2013. "Altruism Within the Family: A Comparison of Father and Mother Using Life Happiness and Life Satisfaction.” Social Indicators Research 111(2):485-510.

Zucker, Gail S., and Bernard Weiner. 1993. "Conservatism and Perceptions of Poverty: An Attributional Analysis." Journal of Applied Social Psychology 23(12):925-943.

\section{FIGURES AND TABLES}

Table 1. Mean, Medians, and Standard Deviation $(N=828)$

\begin{tabular}{lccc}
\hline \hline \multicolumn{1}{c}{ Variable } & Mean & Median & SD \\
\hline Talked to Depressed Friend & 27.68 & 12.00 & 37.610 \\
Individual Responsibility & 3.39 & 4.00 & 1.061 \\
Hard Work & 2.58 & 3.00 & .689 \\
Conservatism & 4.03 & 4.00 & 1.447 \\
Women & .52 & 1.00 & .499 \\
White & .76 & 1.00 & .425 \\
Age & 43.83 & 43.50 & 13.531 \\
Education & 14.26 & 14.00 & 2.974 \\
\hline
\end{tabular}


CONSERVATIVE VALUES AND HELPING BEHAVIOR

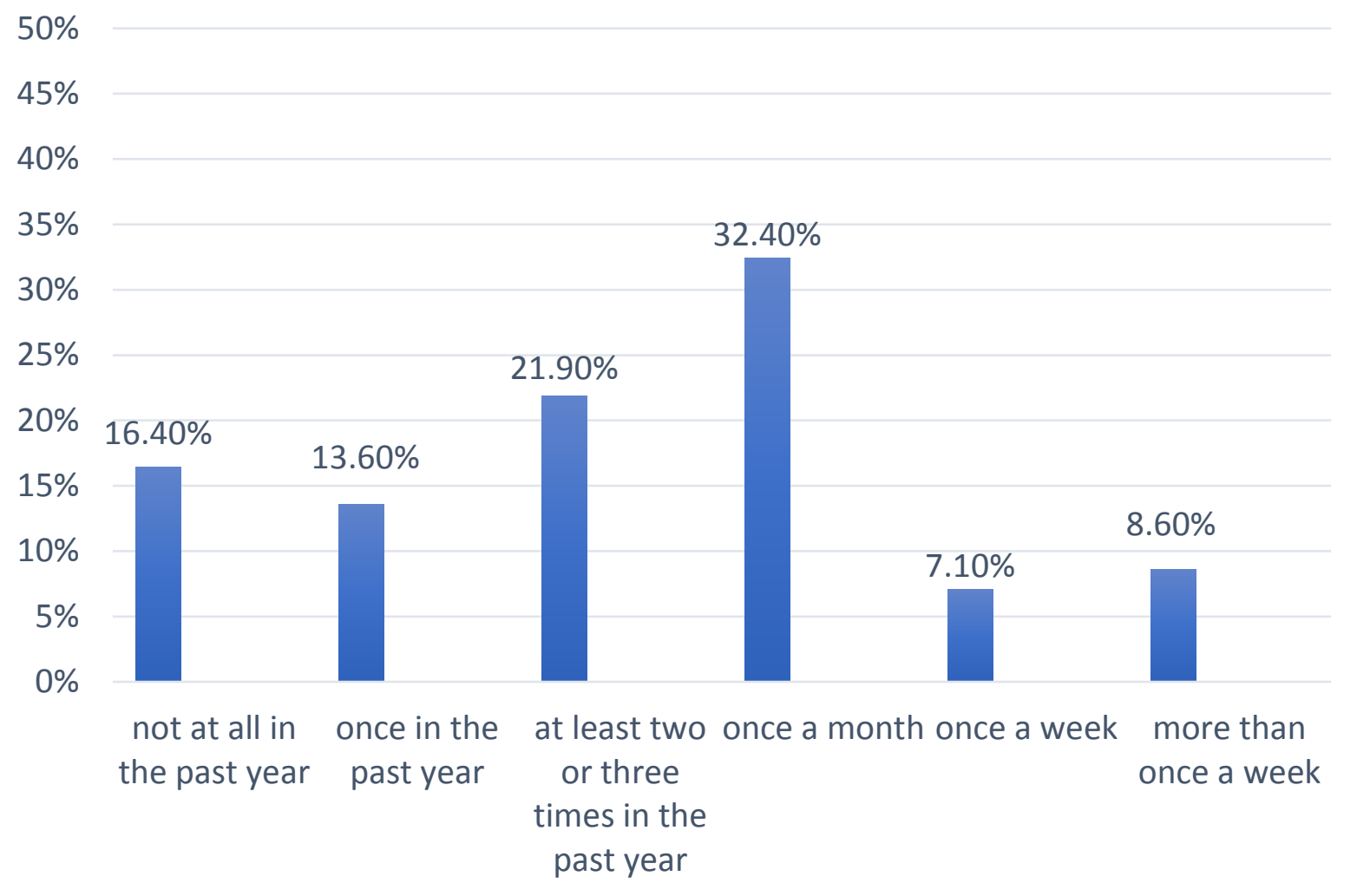

Figure 1. Frequency Respondent Talks to Depressed Friend 


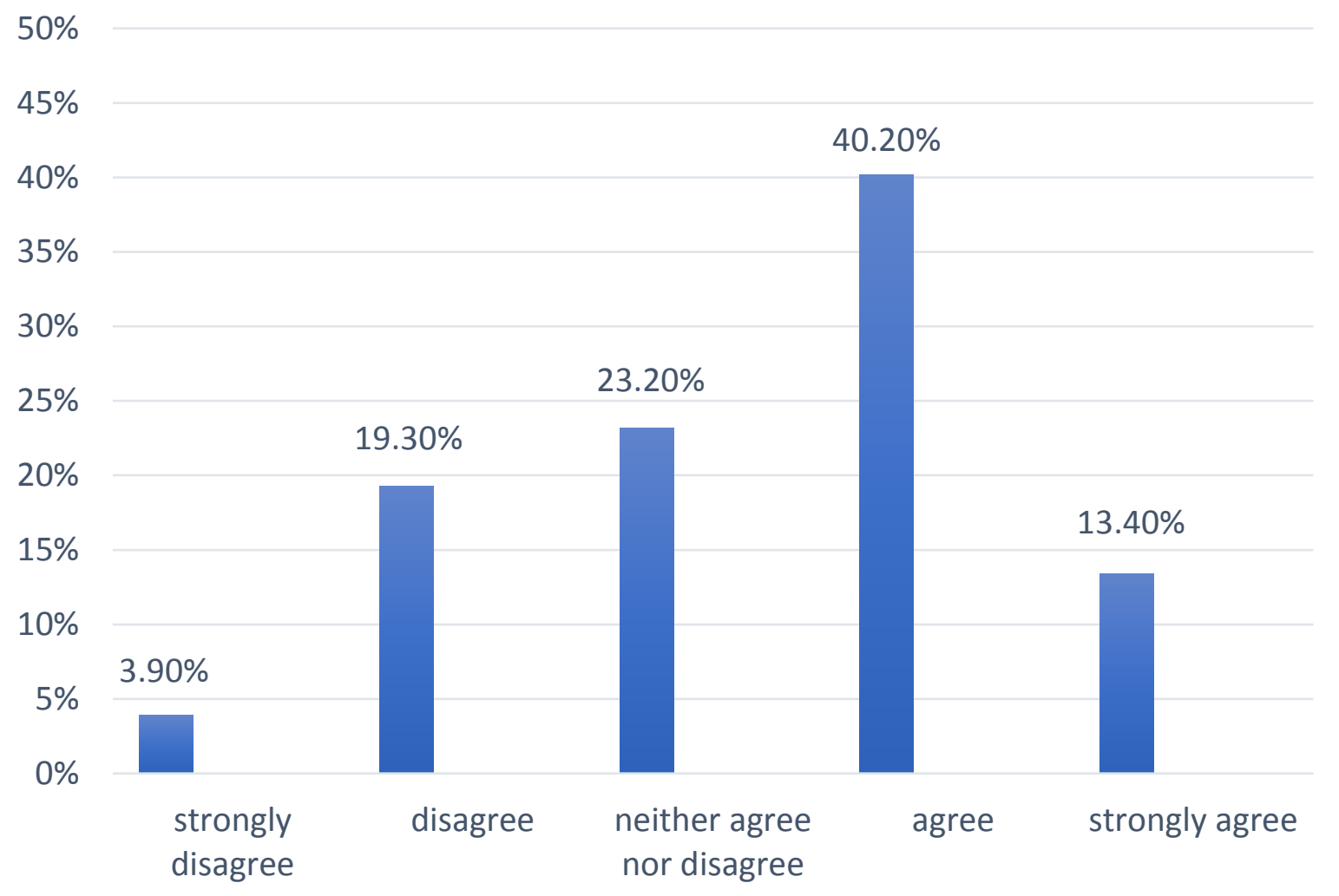

Figure 2. Belief in Individual Responsibility

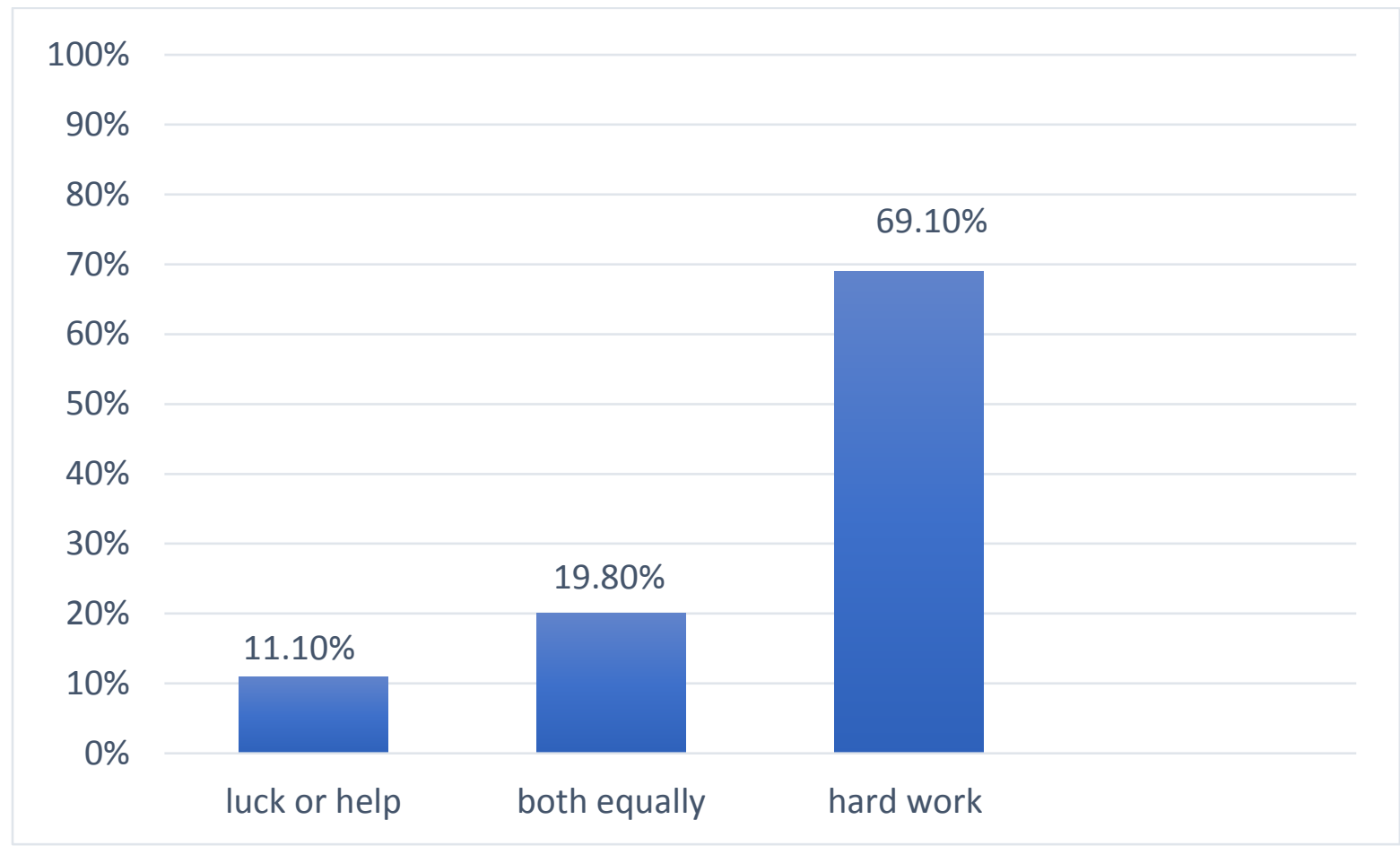

Figure 3. Belief in How People Get Ahead 
CONSERVATIVE VALUES AND HELPING BEHAVIOR

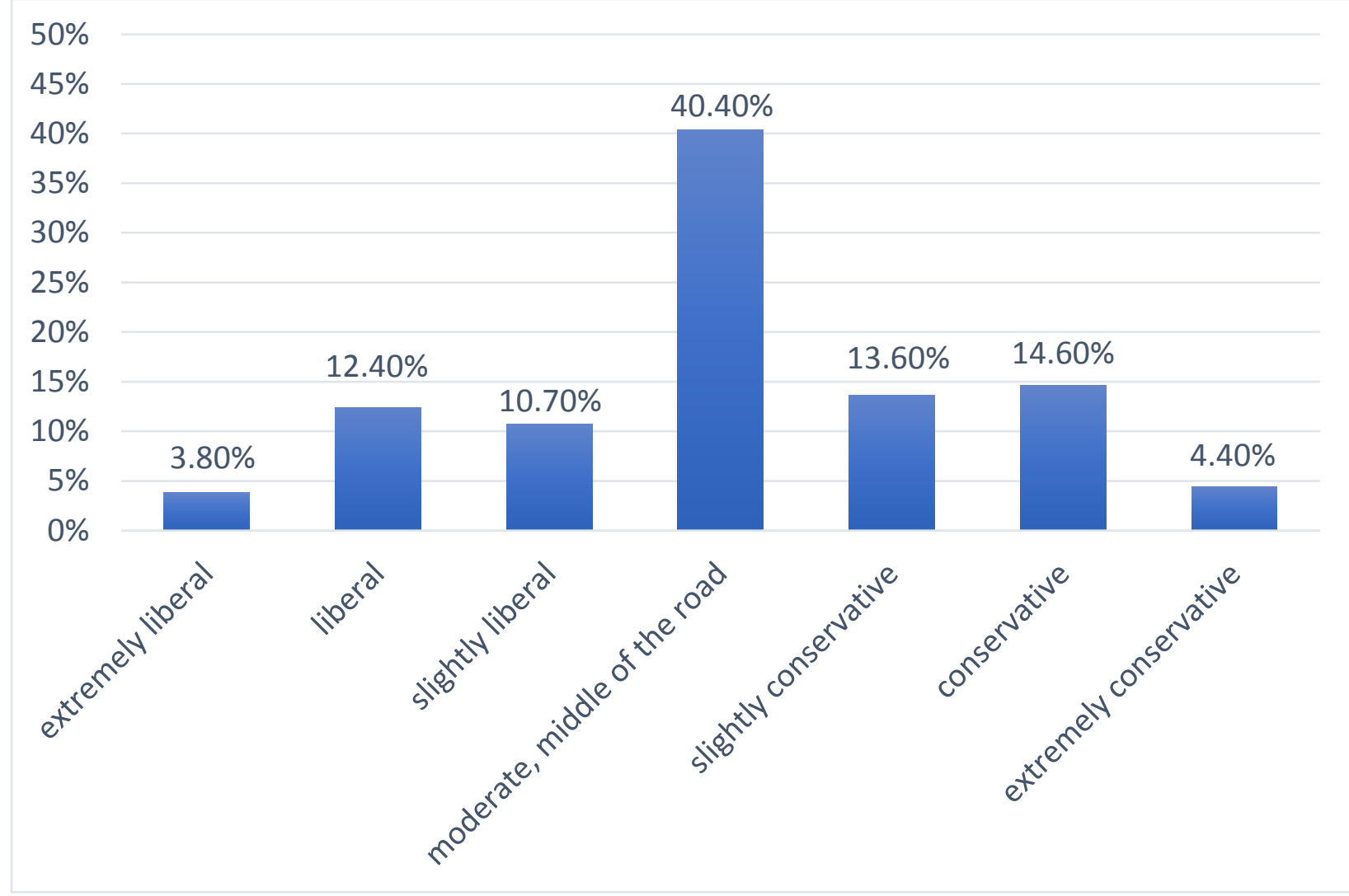

Figure 4. Conservative Views

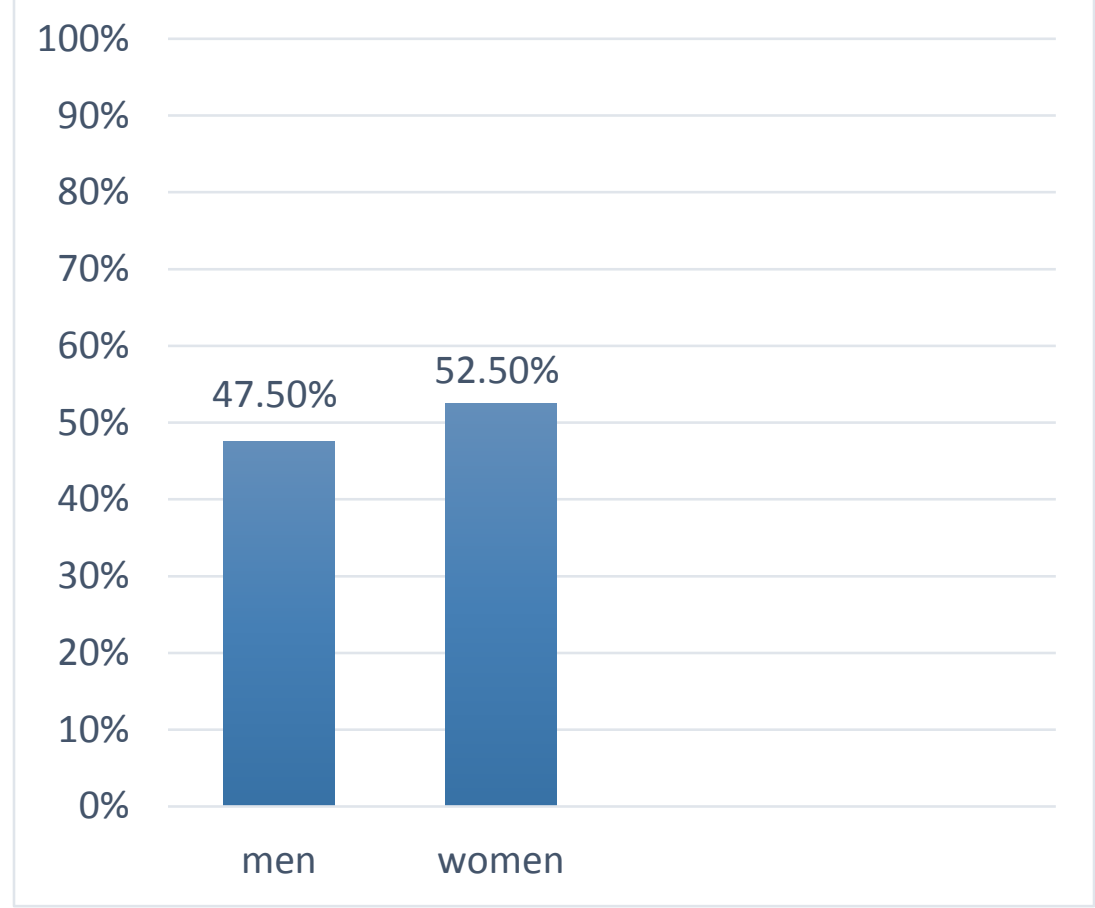

Figure 5. Sex of Respondents 
CONSERVATIVE VALUES AND HELPING BEHAVIOR

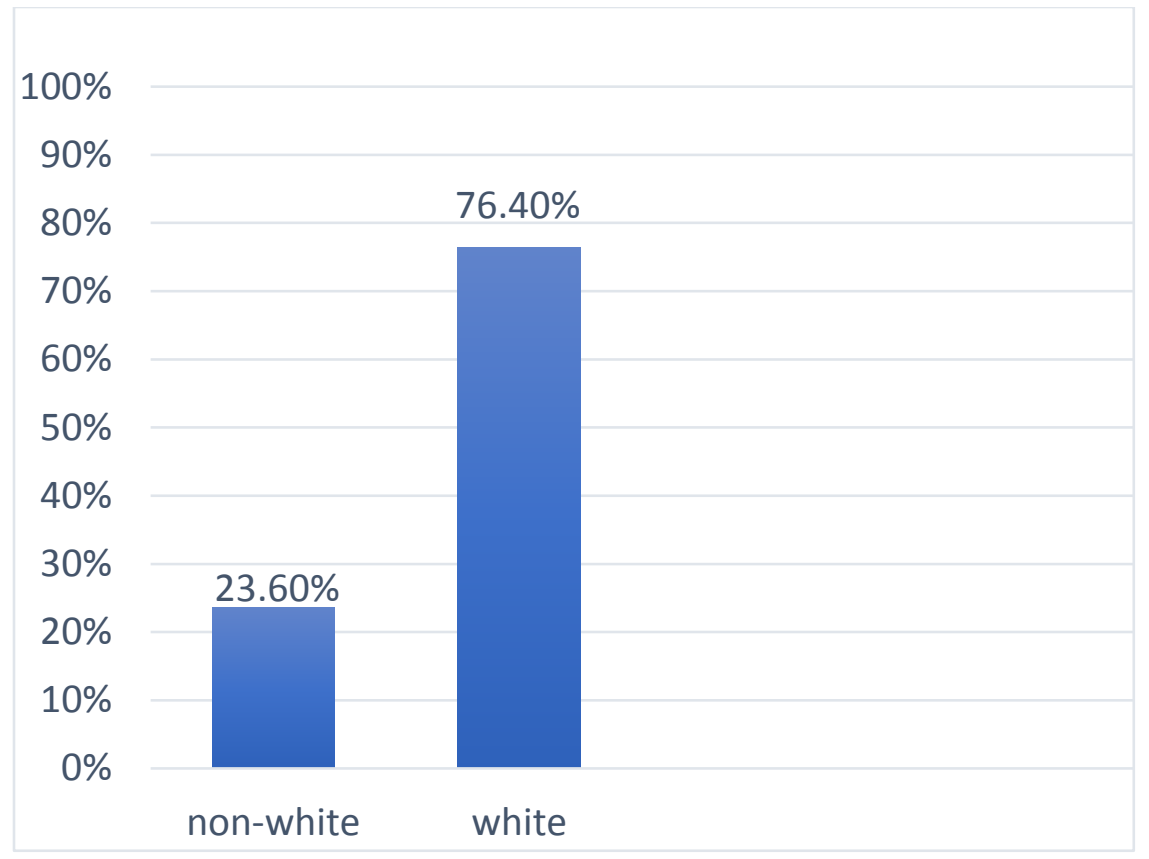

Figure 6. Race of Respondents

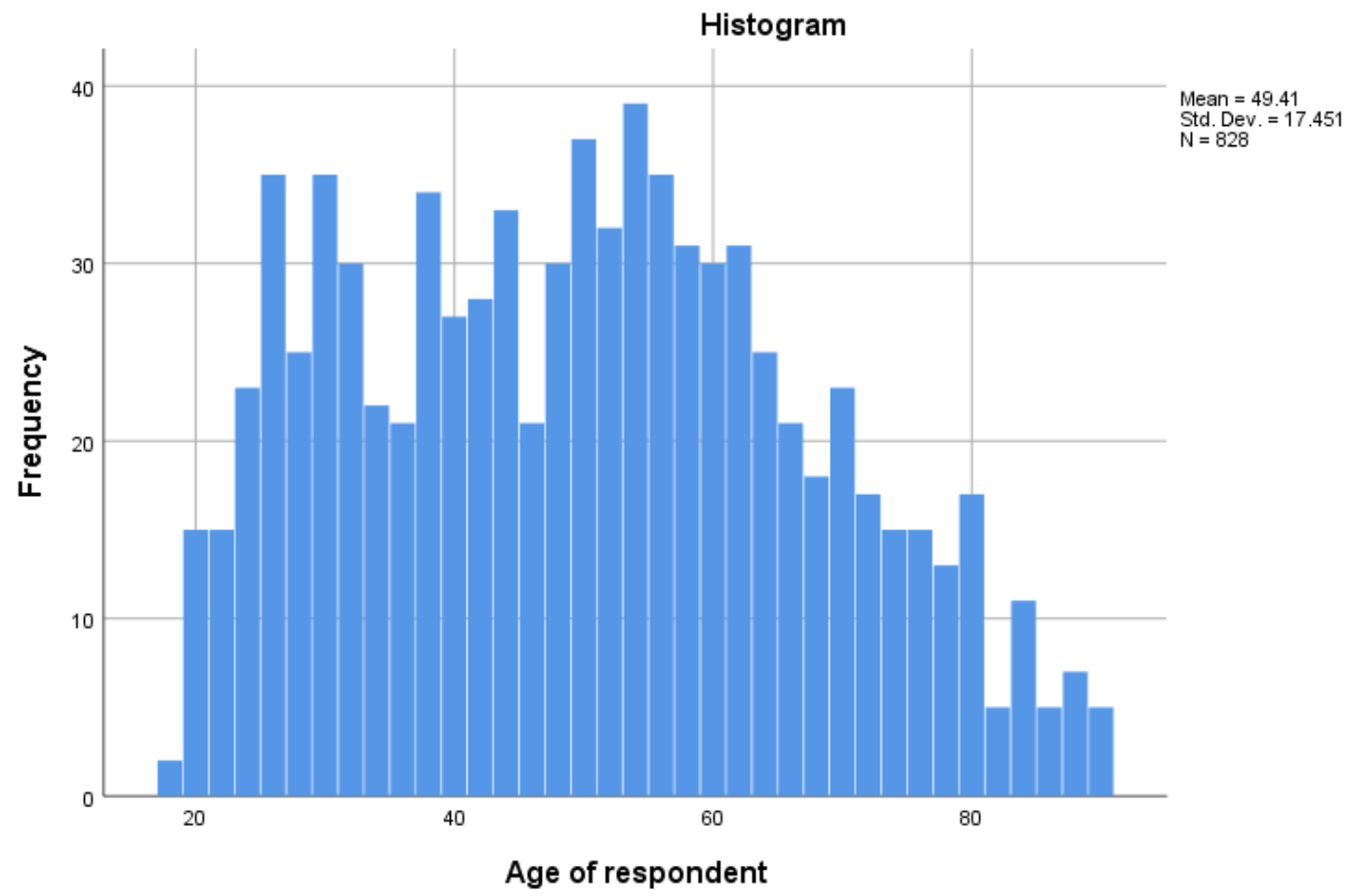

Figure 7. Age of Respondents 
CONSERVATIVE VALUES AND HELPING BEHAVIOR

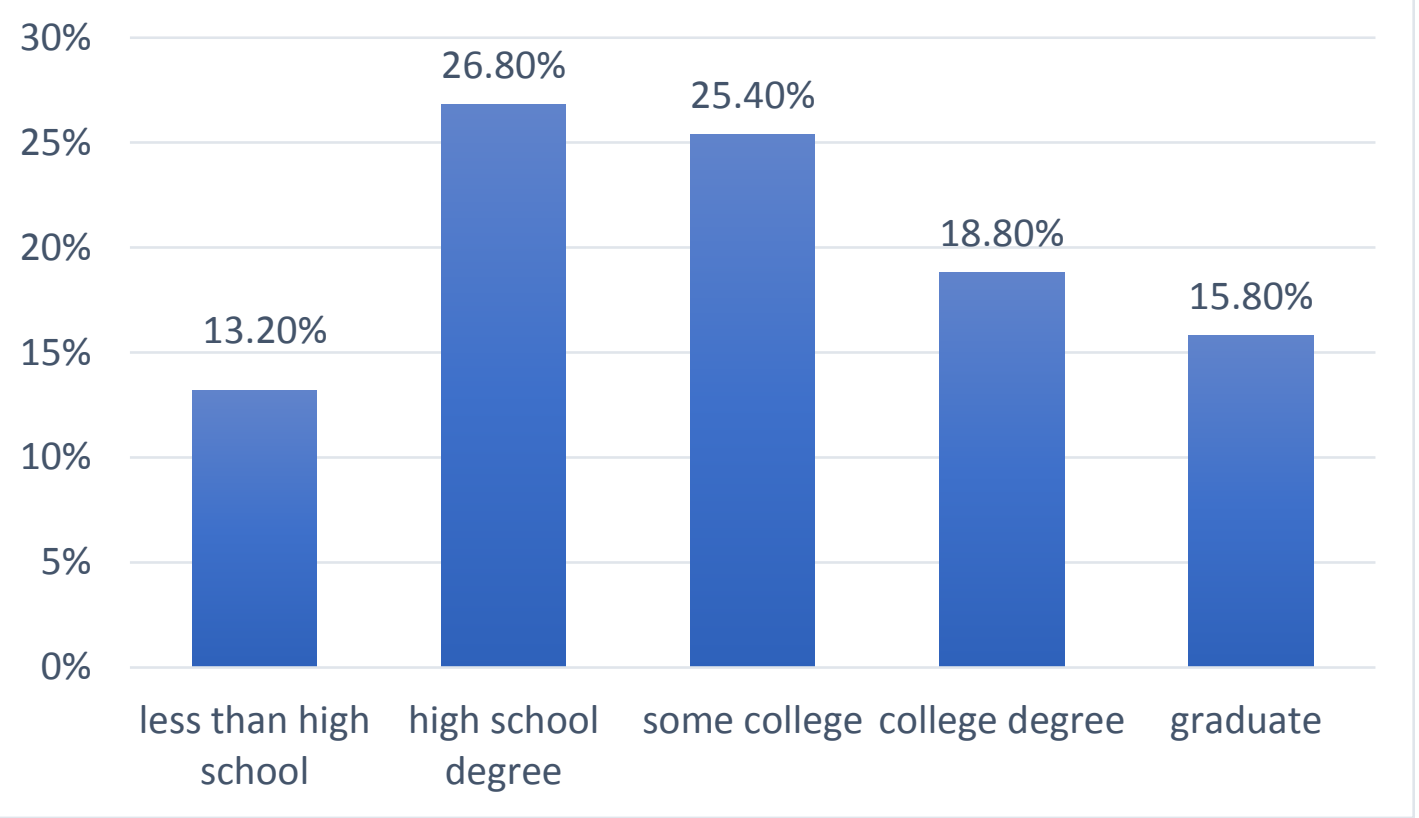

Figure 8. Respondents' Years of Education

Table 2. Correlations $(r)$ between talked to depressed friend and seven variables (listwise deletion, two-tailed test, $N=828$ )

\begin{tabular}{lccccccc}
\hline Variable & $\begin{array}{c}\text { Individual } \\
\text { Responsibility }\end{array}$ & $\begin{array}{c}\text { Hard } \\
\text { Work }\end{array}$ & Conservatism & Women & White & Age & Education \\
\hline $\begin{array}{l}\text { Talked to } \\
\text { Depressed } \\
\text { friend }\end{array}$ & -.070 & -.033 & -.037 & $.228^{*}$ & $-.120^{*}$ & -.087 & .051 \\
$\begin{array}{l}\text { Individual } \\
\text { Responsibility }\end{array}$ & & & & & & & \\
Hard Work & .075 & $.089^{*}$ & $-.116^{*}$ & .037 & $-.093^{*}$ & -.043 \\
Conservatism & & & & & & \\
Women & & $.158^{*}$ & .067 & .071 & -.026 & -.078 \\
White & & & & .030 & $.134^{*}$ & .082 & -.079 \\
Age & & & & & & & \\
\end{tabular}


CONSERVATIVE VALUES AND HELPING BEHAVIOR

Table 3. Regression of Talked to Depressed Friend on All Variables

\begin{tabular}{lrc}
\hline Variable & $b$ & $\beta$ \\
\hline Individual Responsibility & -1.457 & -.041 \\
Hard Work & -1.759 & -.032 \\
Conservatism & -.276 & -.011 \\
Women & 16.588 & $.220^{*}$ \\
White & -8.666 & $-.098^{*}$ \\
Age & -.151 & -.070 \\
Education & .845 & .069 \\
Constant & 31.929 & \\
$R^{2}=.076 ; F(7,820)=9.629 ; p<.01$ & \\
$* p<.01$ & &
\end{tabular}

